\title{
INTRA-ERYTHROCYTIC HAEMOGLOBIN CRYSTALS
}

\author{
BY \\ J. A. M. AGER AND H. LEHMANN \\ From the Departments of Pathology, St. Thomas's Hospital and St. Bartholomew's Hospital, London
}

(RECEIVED FOR PUBLICATION JULY 18, 1957)

When investigating a newly discovered haemoglobin L, using Itano's solubility test (Itano, 1953), a resemblance to sickle cell haemoglobin was noticed inasmuch as solubility was not complete in $2.24 \mathrm{M}$ phosphate buffer. This was later realized to be due to an artefact (see Ager and Lehmann, 1957), but at that time the cells containing haemoglobin $\mathrm{L}$ were tested for sickling by incubation with reducing agents (Daland and Castle, 1948 ; Williams and Mackey, 1949). On prolonged immersion of the erythrocytes in isotonic sodium metabisulphite or bisulphite, it was observed that many contained one or more crystals. This effect had been reported in haemoglobin $\mathrm{C}$ disease, sickle cell-haemoglobin C disease, and haemoglobin C-thalassaemia on immersion of cells in 3\% sodium citrate (Diggs, Kraus, Morrison, and Rudnicki, 1954 ; Kraus and Diggs, 1956). These authors suggested that further work was needed to evaluate whether or not their findings could be used for diagnostic purposes. Since the erythrocytes used by the present authors contained $71 \%$ of normal adult haemoglobin, investigation of erythrocytes containing other types of haemoglobin was undertaken.

\section{Method}

One drop of whole blood (heparinized, oxalated, or citrated) or a drop of washed red cell suspension was placed to one side of two drops of $2 \%$ sodium metabisulphite. No attempt at complete mixing was made and an oblong coverslip ( $1 \frac{1}{2}$ in. by $\frac{3}{4}$ in.) placed on top of the cell suspension which showed a gradation of cell density. Observation was made at 30minute intervals, scanning the whole preparation with the $4 \mathrm{~mm}$. objective and examining in detail with the $2 \mathrm{~mm}$. objective. The use of the higher power lens, preferably with a binocular eyepiece, is necessary to distinguish crystal formation from cell folding and crenation. The preparations were either left unsealed, or sealed with wax, or partially sealed by leaving one short side of the coverslip uncovered by wax. These slides were left on the bench at room temperature (circa $20^{\circ} \mathrm{C}$.) either uncovered or in a moist chamber.
The cells tested contained haemoglobin $\mathrm{C}$ or haemoglobin $A$ or the following haemoglobin mixtures: $A+C, A+D, A+E, A+F, A+H, \stackrel{+}{\dot{\omega}}$ $A+K, A+L, A+S$. Crystals were obtained with $\mathscr{W}_{\mathcal{O}}$ all cells (Fig. 1) excepting those containing 0 haemoglobins $\mathrm{A}+\mathrm{S}$, where, as might be anticipated, sickling persisted, and those containing $\vec{Z}$ haemoglobins $\mathrm{A}$ and $\mathrm{H}$, which developed noncrystalline spherical bodies of presumably de- $\frac{\Phi}{3}$ natured haemoglobin $\mathrm{H}$, the so-called inclusion bodies of Rigas, Koler, and Osgood (1955) (Fig. 2). There was no difference in the ease or degree of $\vec{\oplus}$ crystal formation between the cells containitg haemoglobin $\mathrm{C}$ only and the others.

Although some crystals were observed fro three to three and a half hours in unsealed preparations, better results were obtained in six to eight hours using the partially sealed preparation. As $\frac{\circ}{\Phi}$ in Kraus and Diggs's (1956) experiment of crystal formation in haemoglobin $\mathrm{C}$ containing cells, so in the present observations no crystals were obtained if partial drying out was completely prevented.

When observation was carried out beyond the stage of intra-erythrocytic crystallization it was seen that the cell membrane ruptured, allowing the crystals to redissolve. On some occasions 8 this concentrated solution gave rise to much larger extra-erythrocytic crystals.

In all the haemoglobin types studied the crystals were similar in appearance to those described in haemoglobin C disease by Kraus and Diggs (1956). The number of crystals in a cell varied from one to $\sigma$ five commonly, though more could be seen. In $N$ shape the crystal appears as a long needle or N rod or the shorter form as a square or rhomboid. $\sigma$ Very occasionally cells may be distorted by needlelike crystals and they will then resemble sickle cells. This is, however, infrequent, and, as the other cells with crystals are obviously not sickle cells, it is unlikely that confusion will arise. $\frac{0}{0}$ Nevertheless, the phenomenon may explain the $\stackrel{\mathbb{D}}{\circ}$ finding of $30 \%$ false sickling when Bhatia, Thin, $\frac{?}{\mathbb{Q}}$ 


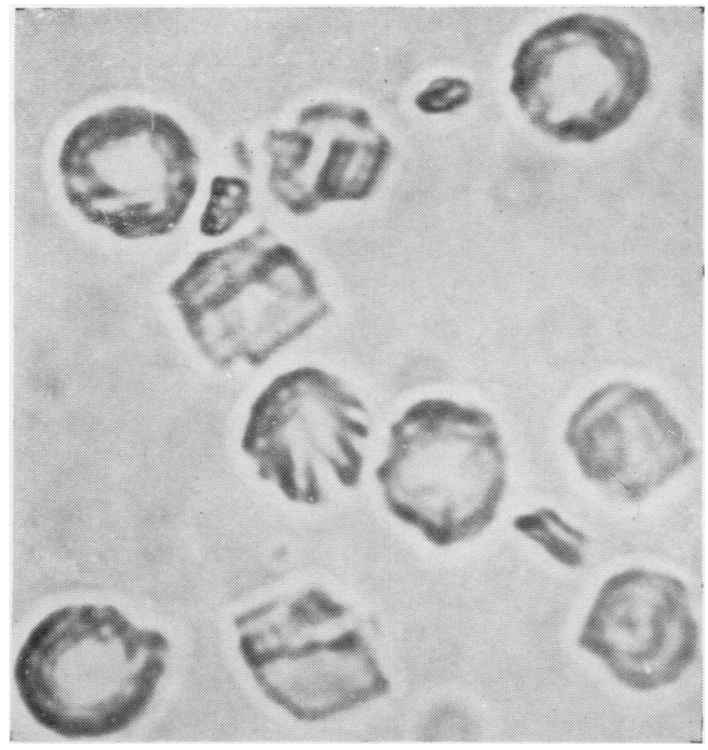

\section{Comment}

These observations suggest that intra-erythrocytic crystallization of haemoglobin in vitro may not be specific in the diagnosis of the haemoglobin $\mathrm{C}$ diseases. On two occasions intra-erythrocytic crystals have been described in fresh blood smears from patients with haemoglobin $\mathrm{C}$ disease following splenectomy (Diggs, Kraus, Morrison, and Rudnicki, 1954; Wheby, Thorup, and Leavell, 1956). For these observations an explanation has still to be found.

\section{Summary}

When a prolonged sickle cell test was performed on red cells containing not sickle cell haemoglobin but a wide variety of other haemoglobins, intraerythrocytic crystals were noted. There did not seem to be a difference between cells containing haemoglobin $\mathrm{C}$ and others. Crystals were also obtained when the suspending solution consisted instead of reducing agents of sodium or potassium

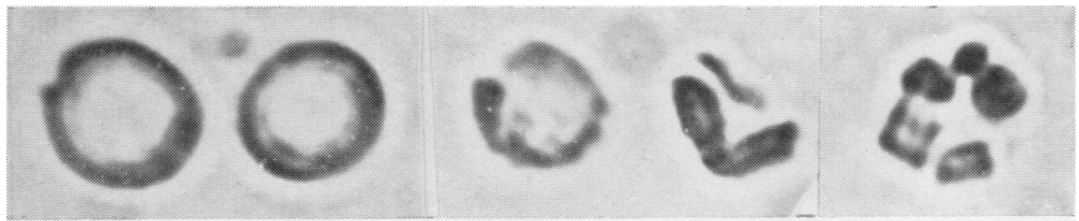

FIG. 1.-Six hours' incubation in isotonic sodium metabisulphite, unsealed preparation in moist chamber at $20^{\circ}$. Cells containing haemoglobins A and L. $\times 2,000$.

Debray, and Cabanes (1955) used the technique of Daland and Castle (1948) in a survey they conducted in Uttar Pradesh (India). These authors noted that most of the "false" sickle cells appeared in the periphery of their unsealed preparations, but that they were not seen in sealed preparations when incubation after prolonged stasis was employed (Scriver and Waugh, 1930).

Crystals were obtained with the following isotonic solutions: sodium bisulphite, sodium metabisulphite, sodium citrate, sodium chloride, or the corresponding potassium salts. It appears, therefore, that the mechanism of production of intraerythrocytic crystals is that an approximately $30 \%$ solution of haemoglobin within the cell membrane is exposed to an extracellular salt solution of slowly increasing osmolarity. If this occurs quickly the haemoglobin will be broken up into two or more peripheral masses and from these masses are formed the multiple small crystals. If the process of supersaturation is more gradual, the haemoglobin is not broken up so frequently and single crystals are formed.

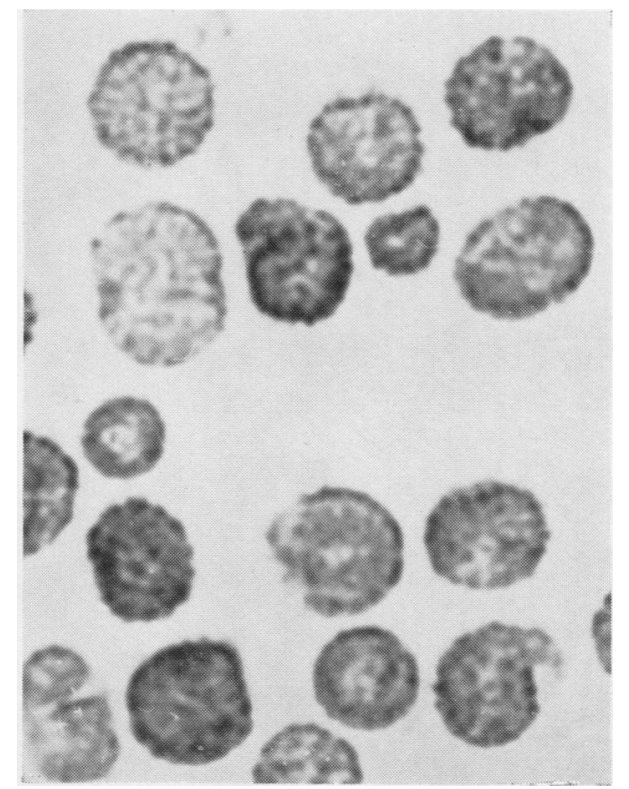

FIG. 2.-Inclusion bodies in cells containing haemoglobins $A$ and $\mathbf{H}$. Incubation as in legend to Fig. 1 followed by staining with cresyl violet. $\times 2,000$ 
citrate or chloride solutions. No crystals were obtained when partial drying was completely prevented.

Our thanks are due to Dr. H. Rice, who kindly supplied us with a sample of fresh blood from a patient with haemoglobin C disease.

\section{REFERENCES}

Ager, J. A. M., and Lehmann, H. (1957). Brit. med. J., 2, 142.

Bhatia, H. M., Thin, J., Debray, H., and Cabanes, J. (1955). Bull. Soc. Anthrop. Paris, 6, 199.
Daland, G. A., and Castle, W. B. (1948). J. Lab. clin. Med., 33, 1082.

Diggs, L. W., Kraus, A. P., Morrison, D. B., and Rudnicki, R. P. T. (1954). Blood, 9, 1172.

Itano, H. A. (1953). Arch. Biochem., 47, 148.

Kraus, A. P., and Diggs, L. W. (1956). J. Lab. clin. Med., 47, 700 .

Rigas, D. A., Koler, R. D., and Osgood, E. E. (1955). Science, 121, 372.

Scriver, J. B., and Waugh, T. R. (1930). Canad. med. Ass. J., 23, 375 .

Williams, A. W., and Mackey, J. P. (1949). J. clin. Path., 2, 141.

Wheby, M. S., Thorup, O. A., and Leavell, B. S. (1956). Blood, 11, 266 . 